\title{
PENGARUH PENGAKUAN MUTU JASA PROGRAM STUDI DAN PENGAKUAN MUTU INSTITUSI TERHADAP MAHASISWA (STUDI KILAS BALIK)
}

\author{
Yustinus Yuniarto \\ Manajemen, Universitas Bunda Mulia, Jakarta. \\ Alamat surel: yyuniarto@yahoo.com \\ Michael Christian \\ Manajemen, Universitas Bunda Mulia, Jakarta. \\ Alamat surel: mchristian@yahoo.com
}

\begin{abstract}
Educational institutions in Indonesia are growing in numbers year by year. This results in increasing competition. Thus, these institutions had tried to reach standardized recognition to its learning process quality (program of study's accreditation) and institution's quality (ISO certification). This research aims at figuring out empirically the impact of these variables to the students' decision (flashback decision). Using SPSS 17.0, this research showed that students' decision was influenced by the recognition of the program of study's quality. On the other side, the decision was not influenced by the institution's quality. Generally, further research needs to elaborate other related factors such as the recognition in achieving IWA 2 or the image of the accreditation bodies.
\end{abstract}

Keywords : department's quality, institution's quality, accreditation

\section{Pendahuluan}

\section{Latar Belakang Masalah}

Sesuai tujuan yang ingin dicapai oleh BAN PT yaitu menjadi Badan Penjaminan Mutu Eksternal Perguruan Tinggi yang terbaik di Indonesia (http://banpt.kemdiknas.go.id), maka secara teratur pengawasan dan evaluasi dilakukan oleh Badan Akreditasi Perguruan Tinggi (BAN PT). Berdasarkan data yang diperoleh dari situs resmi BAN PT khususnya di wilayah Kopertis 3 memperlihatkan semakin banyaknya program studi di tiap jenjangnya yang semakin meningkatkan mutu melalui akreditasi.

Secara khsusus, gambar 1 menjelaskan bahwa program Pascasarjana di wilayah Kopertis 3 masih lebih banyak berstatus B untuk akreditasinya, yaitu sebanyak 166 program. Program pascasarjana di wilayah Kopertis 3 yang memiliki akreditasi A dan C jumlahnya hampir berimbang yaitu 67 dan 57 program studi. Hal ini dapat diartikan bahwa di wilayah Kopertis 3, pengakuan mutu jasa pendidikan tinggi menjadi faktor penting yang harus diperoleh, terlebih akreditasi yang terbaik.

Banyak manfaat yang dapat diperoleh dari diraihnya akreditasi yang baik dari suatu perguruan tinggi, dimana salah satunya adalah pengakuan secara luas akan profesionalitas menjalankan pendidikan, dan juga terjadi peningkatan mutu pembelajaran (McCauley \& Mary, Ann.,2003: 11). Hal ini tercermin dari pengertian dari akreditasi itu sendiri dimana menurut Junior, et al, (2003) "accreditation is a voluntary, nongovernmental process that includes an external review of a school's ability to provide quality programs". Hal ini berarti raihan akan mutu jasa pendidikan tidak hanya pencapaian sekali raih saja, namun membutuhkan komitmen dalam memberikan program pembelajaran yang berkualitas secara berkesinambungan. Hal ini sejalan pula dengan pengakuan di sisi lain yaitu pencapaian mutu dari institusi secara global melalui sertifikasi ISO, dimana ISO 9001 itu sendiri dipahami sebagai suatu standar internasional untuk sistem manajemen kualitas (Gasperz, 2006:1) yang terus mengalami penyesuaian standar, seperti pada ISO 9001:2008.

Peranan yang sangat dominan seperti yang telah dijelaskan di atas terkait dengan pengakuan mutu jasa pendidikan program studi dan pengakuan mutu pendidikan memang berada pada manajemen pelaksana 
institusi pendidikan/perguruan tinggi yang ada. Namun apabila dilihat dari perspektif yang berbeda, maka 2 (dua) hal tersebut dapat berhubungan erat dengan keputusan pengguna jasa utama (calon mahasiswa).

Menurut Khan, Martin (2006), tahapantahapan penting dalam proses keputusan konsumen yaitu: pengenalan masalah (problem recognation), mencari informasi (information search), evaluasi alternatif (evaluation and alternatives), keputusan pembelian (outlet selection and purchase decision), dan perilaku purna beli (postpurchase behaviour).

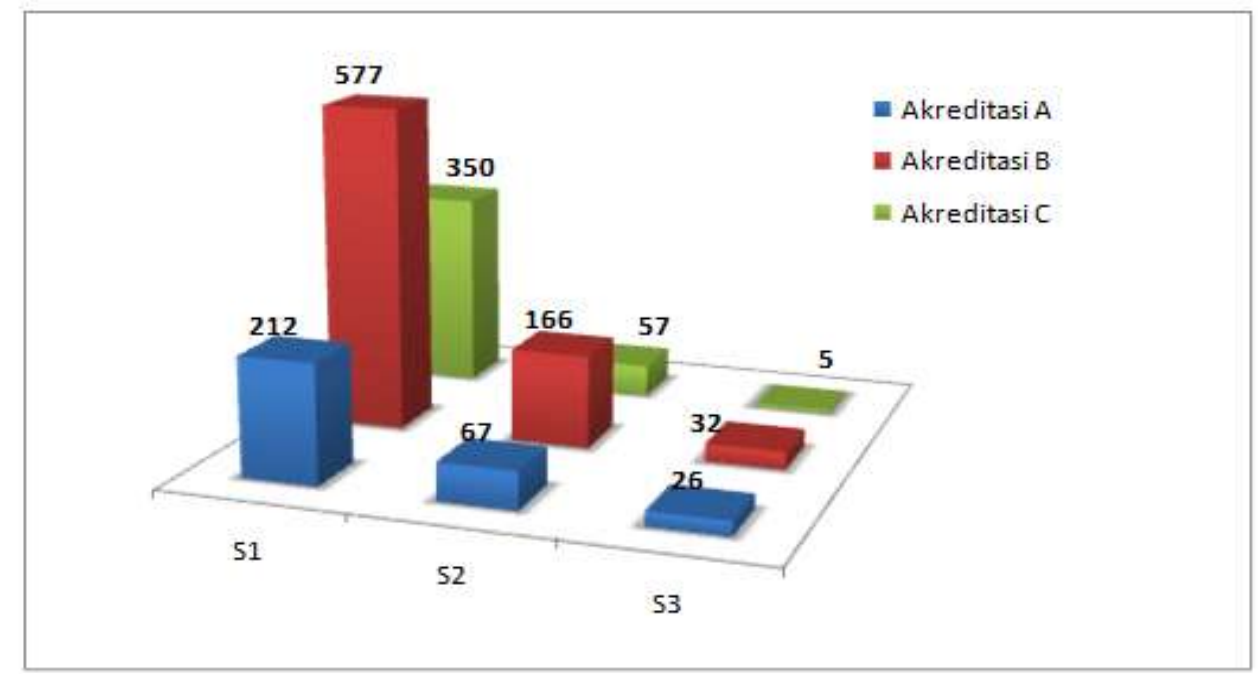

Gambar 1 Jumlah Program Studi Terakreditasi di Wilayah Kopertis 3

Sumber: http://ban-pt.kemdiknas.go.id, 2016

\section{Rumusan Masalah}

Berdasarkan penjelasan latar belakang di atas, maka masalah yang dirumuskan dalam penelitian ini adalah:

a. Apakah ada pengaruh antara pengakuan mutu jasa program studi terhadap keputusan mahasiswa dalam memilih program Magister Manajemen di Universitas swasta X di Jakarta?

b. Apakah ada pengaruh antara pengakuan mutu institusi terhadap keputusan mahasiswa dalam memilih program Magister Manajemen di Universitas swasta X di Jakarta?

c. Apakah ada pengaruh antara pengakuan mutu jasa program studi dan pengakuan mutu institusi terhadap keputusan mahasiswa dalam memilih program Magister Manajemen di Universitas swasta X di Jakarta?

\section{Tujuan Penelitian}

Penelitian ini dilakukan bertujuan untuk mengetahui apakah terdapat pengaruh antara pengakuan mutu jasa pendidikan tinggi dan Pengakuan mutu institusi terhadap keputusan melanjutkan studi program Magister Manajemen di universitas swasta $\mathrm{X}$ di Jakarta. Penelitian ini dilakukan dengan tujuan untuk:

1. Mengetahui dan menjelaskan besarnya pengaruh pengakuan mutu jasa program studi terhadap keputusan mahasiswa dalam memilih program Magister Manajemen di Universitas swasta X di Jakarta.

2. Mengetahui dan menjelaskan besarnya pengaruh pengakuan mutu institusi terhadap keputusan mahasiswa dalam memilih program Magister Manajemen di Universitas swasta X di Jakarta.

3. Mengetahui dan menjelaskan besarnya pengaruh pengakuan mutu jasa program studi dan pengakuan mutu institusi terhadap keputusan mahasiswa dalam memilih program Magister Manajemen di Universitas swasta $\mathrm{X}$ di Jakarta? 


\section{Rerangka Berpikir \& Hipotesis}

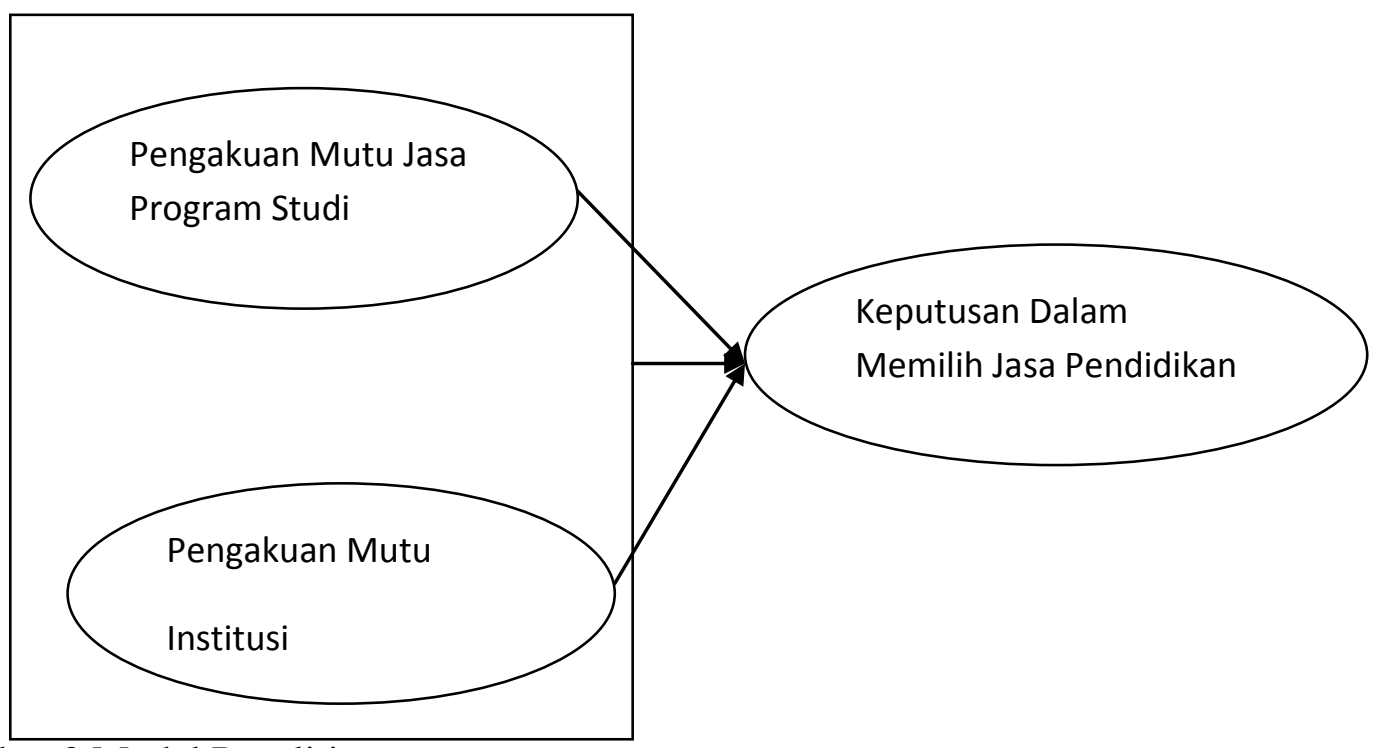

Gambar 2 Model Penelitian

Hipotesis 1 :

Pengakuan mutu jasa program Magister berpengaruh terhadap keputusan calon mahasiswa memilih jasa pendidikan.

Hipotesis 2:

Pengakuan mutu institusi pendidikan tinggi berpengaruh terhadap keputusan calon mahasiswa memilih jasa pendidikan.

Hipotesis 3:

Pengakuan mutu jasa program Magister dan mutu institusi prendidikan tinggi secara bersama berpengaruh terhadap keputusan calon mahasiswa memilih jasa pendidikan.

\section{Metode Penelitian}

Data dalam penelitian ini adalah data primer yang artinya data diperoleh dari objeknya dan diolah sendiri oleh suatu organisasi atau perorangan. (Supranto, 2000:8). Jenis penelitin ini adalah penelitian sebab akibat dengan metode pengumpulan data menggunakan kuesioner. Dengan menggunakan telaah kilas balik, data diperoleh dari penyebaran kuesioner kepada responden yaitu mahasiswa program Magister Manajemen di Universitas Swasta $\mathrm{X}$ di Jakarta.

\section{Populasi \& Sampel}

Dalam penelitian ini, yang merupakan populasi adalah seluruh mahasiswa program studi Magister Manajemen Universitas Swasta X di Jakarta yang berjumlah 38 mahasiswa. Sampel yang ditentukan sebanyak 35 mahasiswa. Jumlah ini diperoleh dengan menggunakan rumus Slovin dimana hasil dari perhitungan rumus tersebut sebanyak $(34.70=35)$. Alasan penggunaan sampel adalah karena keterbatasan waktu dan kesempatan dalam menyebarkan kuesioner kepada responden yang berhalangan dengan waktu penyebaran. 
Operasionalisasi Peubah

Operasionalisasi peubah dilakukan untuk mengukur konsep yang abstrak.
Operasionalisasi peubah dalam penelitian ini adalah sebagai berikut:

Tabel 1. Operasionalisasi Peubah

\begin{tabular}{|c|c|c|c|c|}
\hline Peubah & Definisi & Indikator & Sumber & Skala \\
\hline $\begin{array}{l}\text { Pengakuan } \\
\text { Mutu Jasa } \\
\text { Program } \\
\text { Studi (X1) }\end{array}$ & $\begin{array}{l}\text { Sistem dalam perguruan } \\
\text { tinggi yang melibatkan } \\
\text { sumber daya manusia } \\
\text { (mahasiswa dan dosen), } \\
\text { sumber daya fisik } \\
\text { (infrastruktur), sumber } \\
\text { daya keuangan yang } \\
\text { pada prosesnya terkait } \\
\text { dengan proses dan } \\
\text { kegiatan edukasi, } \\
\text { seeperti: kurikulum, } \\
\text { manajemen dan } \\
\text { mekanisme pendukunng } \\
\text { lainnya. }\end{array}$ & $\begin{array}{l}\text { a. Visi Program Studi } \\
\text { b. Daya saing akreditasi } \\
\text { c. Kompetensi pengajar } \\
\text { d. Karakteristik perkuliahan } \\
\text { sesuai dengan visi program } \\
\text { studi yang ingin dicapai } \\
\text { e. Keunggulan metode } \\
\text { perkuliahan } \\
\text { f. Mata kuliah yang ditawarkan } \\
\text { sesuai dengan kebutuhan } \\
\text { mahasiswa } \\
\text { g. Desain kurikulum sesuai } \\
\text { dengan kebutuhan dunia } \\
\text { industri }\end{array}$ & $\begin{array}{l}\text { Menon, et al ; } \\
2007\end{array}$ & Rating \\
\hline $\begin{array}{l}\text { Pengakuan } \\
\text { mutu } \\
\text { institusi } \\
(\mathrm{X} 2)\end{array}$ & $\begin{array}{l}\text { Suatu standar } \\
\text { menjalankan } \\
\text { manajemen pendidikan } \\
\text { yang berkualitas dimana } \\
\text { bertujuan untuk } \\
\text { memenuhi kebutuhan } \\
\text { konsumen yang sesuai } \\
\text { dengan aturan dan } \\
\text { hukum yang berlaku } \\
\text { dan memungkinkan } \\
\text { untuk mencapai } \\
\text { kepuasan pelanggan. }\end{array}$ & $\begin{array}{ll}\text { a. } & \text { Aktif dalam memberikan } \\
\text { informasi perkkuliahan } \\
\text { b. Tanggap dalam melayani } \\
\text { mahasiswa } \\
\text { c. Konsistensi dalam } \\
\text { penyampaian informasi } \\
\text { d. Penyampaian informasi } \\
\text { secara tatap muka sesuai } \\
\text { dengan informasi yang ada di } \\
\text { portal dalam } \\
\text { e. Kemampuan yang } \\
\text { memenuhi layanan yan } \\
\text { dijanjikan kepada mahasiswa } \\
\text { f. Pada prosesnya, petugas } \\
\text { layanan mahasiswa mampu } \\
\text { memberikan layanan yang } \\
\text { dibutuhkan mahasiswa } \\
\text { g. Jaminan akan ruang } \\
\text { perkuliahan yang nyaman } \\
\text { h. Kemampuan dalam } \\
\text { memberikan solusi atas } \\
\text { permasalahan mahasiswa } \\
\text { i. Ketanggapan dalam melayani } \\
\text { mahasiswa }\end{array}$ & $\begin{array}{l}\text { Sumaedi \& } \\
\text { Bakti, I Gede } \\
\text { Mahatma } \\
\text { Yuda }\end{array}$ & Rating \\
\hline $\begin{array}{l}\text { Keputusan } \\
\text { mahasiswa } \\
\text { memilih } \\
\text { jasa } \\
\text { pendidikan } \\
\text { (Y) }\end{array}$ & & 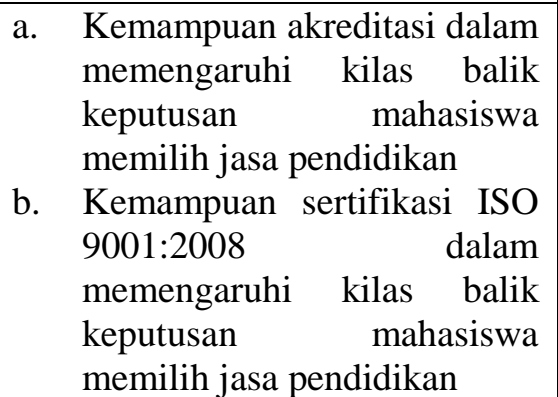 & Melyana; 2010 & Rating \\
\hline
\end{tabular}

Sumber: peneliti 


\section{Uji Kesahian dan Kehandalan}

Suatu alat Alat ukur harus dapat dipercaya (sahih) dan handal. Untuk itu perlu diuji Kesahian dan kehandalannya agar dapat diketahui seberapa cermat suatu kuesioner melakukan fungsi ukurnya. Uji kesahian dilakukan dengan cara menghitung nilai korelasi antara data pada masing-masin pernyataan dengan skor total menggunakan rumus teknik korelasi Product Moment Pearson dengan $\alpha=5 \%$. Kriteria pengujian dengan membandingkan antara $r$ hasil dengan $r$ tabel, jika $r$ hasil $>r$ tabel maka instrumen dianggap sahih.

Menurut Sekaran (2006: 324), uji kehandalan ini akan menunjukkan konsistensi dan stabilitas dari suatu skor (skala pengukuran). Jika hasil uji kehandalan menunjukkan angka $<0,60$ maka kehandal an dianggap buruk, indikator yang digunakan tidak handal. Sebaliknya, bila hasil > 0,60 maka kehandalan bisa diterima dan indikatornya handal .

\section{Uji Normalitas}

Menurut Suliyanto (2011: 69), uji normalitas dimaksudkan untuk menguji apakah nilai residual yang telah distandarisasi pada model regresi berdistribusi normal atau tidak. Tidak terpenuhinya normalitas pada umumnya disebabkan karena distribusi data yang dianalisis tidak normal, karena terdapat nilai ekstrem pada data yang diambil. Nilai ekstrim ini dapat terjadi karena adanya kesalahan dalam pengambilan sampel, bahkan karena kesalahan dalam melakukan input data atau memang karena karakteristik data tersebut sangat jauh dari rata - rata.

Nilai residual dikatakan berdistribusi normal jika nilai residual terstandarisasi tersebut sebagian besar mendekati rata ratanya. Nilai residual terstandarisasi yang berdistribusi normal jika digambarkan dengan bentuk kurva akan membentuk gambar lonceng (bell-shaped curve) yang kedua sisinya melebar sampai tidak terhingga. Pada penelitian ini, penulis menggunakan analisis grafik untuk menguji nilai residual.

\section{Uji Multikolinieritas}

Menurut Suliyanto (2011: 81), Multikolinieritas berarti terjadi korelasi linier yang mendekati sempurna antar lebih dari dua peubah bebas. Uji multikolinieritas bertujuan untuk menguji apakah dalam model regresi yang terbentuk ada korelasi yang tinggi atau sempurna di antara peubahpeubah bebas atau tidak.Jika dalam model regresi yang terbentuk terdapat korelasi yang tinggi atau sempurna di antara peubahpeubah bebas maka model regresi tersebut dinyatakan mengandung gejala multikolinier. Terdapat beberapa cara untuk menguji multikolinieritas. Dalam penelitian ini, penulis menguji multikolinieritas dengan TOL (Tolerance) dan TIF (Variance Inflation Factor).

\section{Uji Heteroskedastisitas}

Menurut Suliyanto (2011: 96), heteroskedastisitas berarti ada varian peubah pada model regresi yang tidak sama (konstan). Sebaliknya, jika varian peubah pada model regresi memiliki nilai yang sama (konstan) maka disebutkan dengan homoskedastisitas. Yang diharapkan pada model regresi adalah yang homoskedastisitas. Dalam penelitian ini penulis menggunakan metode Glejser untuk menguji heteroskedastisitas.

\section{Uji Regresi Berganda}

Bentuk rumus secara umum dari sebuah persamaan regresi berganda dapat dilihat sebagai berikut:

$$
\begin{aligned}
& \hat{Y}=a+b_{1} X_{1}+b_{2} X_{2}+b_{3} X_{3}+\ldots+b_{j} X_{j}+ \\
& b_{k} X_{k}
\end{aligned}
$$

Dalam penelitian ini rumusnya adalah:

$$
\hat{Y}=a+b_{1} X_{1}+b_{2} X_{2}
$$

Keterangan:

$\hat{Y} \quad=$ Keputusan mahasiswa memilih jasa pendidikan

$\mathrm{a} \quad=$ Konstanta dari persamaan regresi

$\mathrm{b}_{1}=$ Koefisien regresi parsial yang menunjukkan besarnya pengaruh dari pengakuan mutu jasa program magister (X1) terhadap 
keputusan mahasiswa memilih jasa pendidikan (Y) apabila pengakuan mutu institusi (X2) tetap.

$\mathrm{b}_{2}=$ Koefisien regresi parsial yang menunjukkan besarnya pengaruh dari pengakuan mutu institusi (X2) terhadap keputusan mahasiswa memilih jasa pendidikan $(\mathrm{Y})$ apabila pengakuan pengakuan mutu jasa program magister (X1) tetap.

$\mathrm{X}_{1}=$ Pengakuan mutu jasa program studi

$\mathrm{X}_{2}=$ Pengakuan mutu institusi

\section{Pengujian Hipotesis Statistik Secara Simultan}

Jika nilai $F$ yang diperoleh dari tabel ANOVA dengan tingkat toleransi kesalahan sebesar 5\%, dibandingkan dengan nilai $\mathrm{F}$ tabel adalah lebih besar, maka secara bersama (simultan) peubah-peubah bebas memengaruhi peubah gayut, atau nilai $p$ value (p-significance) dari $\mathrm{F}$ hitung kurang dari 0.05 dengan tingkat signifikansi $\alpha=5 \%$.

\section{Pengujian Hipotesis Statistik Secara Parsial}

Uji $\mathrm{t}$ ini digunakan untuk menguji koefisien - koefisien regresi secara parsial dari peubah bebas terhadap peubah gayut (Supranto, 2000: 156 ).

Rumus nilai uji statistik $t\left(t_{0}\right)$ :

$t_{0}=\underline{b}_{\mathrm{i}} \quad$ dimana $_{b j}=$ standard error

Setelah mendapatkan nilai $t_{0}$, tentukan $\alpha$, cari $\mathrm{t}_{\alpha}$ atau $\mathrm{t}_{\alpha / 2}$ dari tabel $\mathrm{t}$ dengan $\mathrm{df}=\mathrm{n}-3$

Kesimpulan :

Dengan menggunakan $a=5 \%$, maka hipotesis statistik yang digunakan adalah:

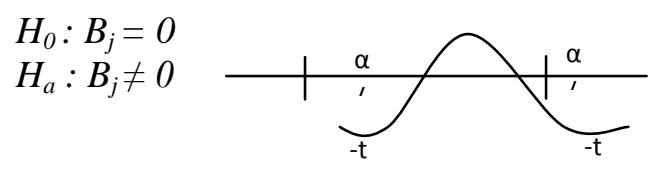

Artinya adalah :

$H_{0}$ ditolak kalau $t_{0} \leq-\mathrm{t} \alpha / 2$ atau $t_{0} \geq-\mathrm{t}_{\alpha / 2}$

$H_{0}$ diterima kalau $-\mathrm{t}_{\alpha / 2}<t_{0}<\mathrm{t}_{\alpha / 2}$

Atau :

Jika nilai sig $\leq 0.05, H_{0}$ ditolak

Jika nilai sig $>0.05, H_{0}$ diterima

\section{Koefisien Determinasi}

Koefisien determinasi dilakukan untuk melihat seberapa besar besar peubah bebas dapat mempengaruhi peubah gayut. Koefisien determinasi dapat dilihat dari nilai $\mathrm{R} 2$.

\section{Hasil dan Pembahasan \\ Deskripsi Profil Responden}

Data yang diambil di lapangan sebagai sampel pada penelitian ini adalah sebesar 35 responden dari populasi sebanyak 38 responden yang berstatus sebagai mahasiswa Magister Manajemen di Universitas X di Jakarta. Responden merupakan mahasiswa yang sedang mengambil program Magister Manajemen di Universitas X di Jakarta. Berdasarkan data yang telah diolah, maka jumlah keterwakilan responden dilihat dari angkatan program studi adalah sebagai berikut:

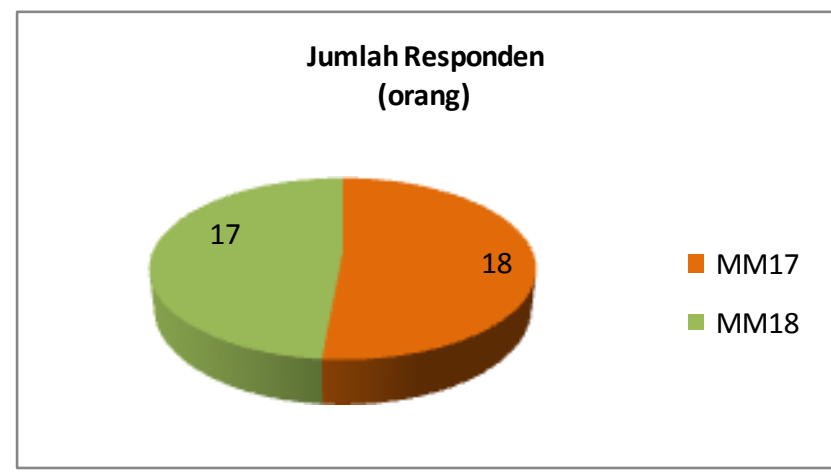

Gambar 3- Deskripsi Profil Responden

Sumber: Data Primer, $(\mathrm{n}=35)$ 


\section{Hasil uji Kesahian dan Kehandalan}

Uji Kesahian dan kehandalan tahap pertama dilakukan terhadap 35 responden yang diolah dengan menggunakan aplikasi
Statistical Package for the Social Science (SPSS) versi 16.0, dengan hasil sebagai berikut:

Tabel 2. Hasil Uji Kesahian

\begin{tabular}{|l|c|c|}
\hline \multicolumn{1}{|c|}{ Item } & $\begin{array}{c}\text { Corrected Item-Total } \\
\text { Correlation }\end{array}$ & Keterangan \\
\hline Item1 - Akreditasi1 & 0.628 & Sahih \\
\hline Item2 - Akreditasi2 & 0.552 & Sahih \\
\hline Item3 - Akreditasi3 & 0.645 & Sahih \\
\hline Item4 - Akreditasi4 & 0.595 & Sahih \\
\hline Item5 - Akreditasi5 & 0.639 & Sahih \\
\hline Item6 - Akreditasi6 & 0.566 & Sahih \\
\hline Item7 - Akreditasi7 & 0.527 & Sahih \\
\hline Item8 - Akreditasi8 & 0.624 & Sahih \\
\hline Item9 - ISO1 & 0.421 & Sahih \\
\hline Item10 - ISO2 & 0.471 & Sahih \\
\hline Item11 - ISO3 & 0.551 & Sahih \\
\hline Item12 - ISO4 & 0.466 & Sahih \\
\hline Item13 - ISO5 & 0.682 & Sahih \\
\hline Item14 - ISO6 & 0.478 & Sahih \\
\hline Item15 - ISO7 & 0.376 & Sahih \\
\hline Item16 - ISO8 & 0.658 & Sahih \\
\hline Item17 - ISO9 & 0.612 & Sahih \\
\hline Item18 - Keputusan1 & 0.519 & Sahih \\
\hline Item19 - Keputusan2 & 0.612 & Sahih \\
\hline TotalAkreditasi & 0.818 & Sahih \\
\hline TotalISO & 0.750 & Sahih \\
\hline TotalKeputusan & 0.572 & Sahih \\
\hline Sumber Hasi Pengolahan & \\
\hline
\end{tabular}

Sumber: Hasil Pengolahan SPSS 16.0, $(\mathrm{n}=35)$

Berdasarkan Tabel 2, nilai $\mathrm{r}$ hitung keseluruhan indikator memiliki nilai lebih besar dari nilai $r$ tabel (0.334). Hal ini menunjukkan bahwa seluruh pertanyaan kuesioner dinyatakan sahih.
Uji kehandalan ditujukan untuk mengetahu konsistensi pengukuran ulang dari setiap butir yang ada. Berdasarkan data yang telah diolah maka diperoleh hasil sebagai berikut:

Tabel 3 - Hasil Uji Kehandalan

Reliability Statistics

\begin{tabular}{|c|c|}
\hline Cronbach's Alpha & N of Items \\
\hline, 891 & 19 \\
\hline
\end{tabular}

Sumber: Hasil Pengolahan SPSS 16.0, $(n=35)$

Tabel 3 menunjukkan bahwa nilai 0,891 dimana memiliki nilai alpha $>0,60$ kehandalan pada Cronbach's Alpha sebesar sehingga item dapat dikatakan handal. 


\section{Pengujian Normalitas Dengan Analisis Grafik}

Berdasarkan gambar 4, diperoleh hasil uji normalitas dengan menggunakan analisis grafik sebagai berikut:

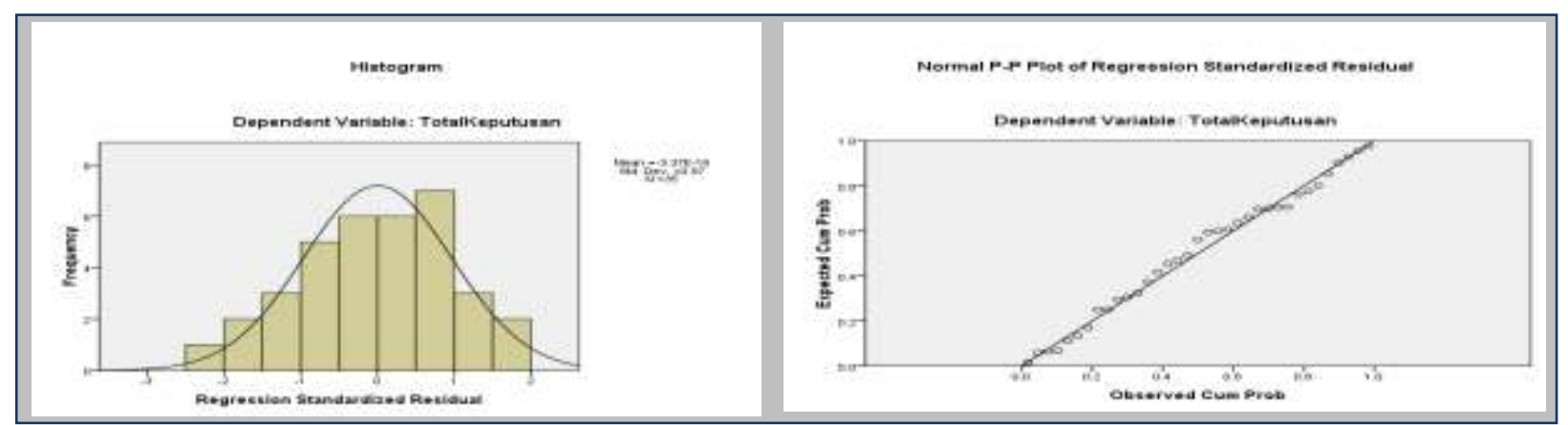

Gambar 4 - Hasil Pengujian Normalitas Dengan Analisis Grafik

Sumber: Hasil Pengolahan SPSS 16.0, $(n=35)$

Dari grafik histogram dan regression standardized residual membentuk gambar seperti lonceng dan tampilan Normal P-P Plot Regression Standardized meperlihatkan bahwa titik-titik menyebar di sekitar garis diagonal sehingga analisis regresi layak digunakan.

Pengujian Multikolinieritas dengan TOL (Tolerance) dan Variance Inflation Factor (VIF)

Berdasarkan Tabel 4 diperoleh hasil nilai Tolerance dan VIF untuk masing-masing peubah bebas sebesar 0,601 dan 1,663. Hasil ini menunjukkan bahwa nilai Tolerance dan VIF tidak melebihi angka 10 yang berarti tidak terjadi gejala multikolinieritas terhadap model regresi yang terbentuk.

Tabel 4 - Hasil Pengujian Multikolinieritas dengan TOL (Tolerance)

\begin{tabular}{|c|c|}
\multicolumn{2}{|c|}{ dan Variance Inflation F } \\
\hline Collineartity Statistics \\
\hline Tolerance & VIF \\
\hline 0.601 & 1.663 \\
\hline 0.601 & 1.663 \\
\hline
\end{tabular}

Sumber: Hasil Pengolahan SPSS 16.0, $(n=35)$ 
Pengujian Heteroskedastisitas Dengan Metode Grafik

Dengan menggunakan SPSS 16.0, maka diperoleh hasil uji heteroskedastisitas dengan metode grafik yaitu scatterplot dalam penelitian ini tidak membentuk sebuah pola (bergelombang, melebar kemudian menyempit), oleh karena itu maka pada data tersebut tidak terjadi heteroskedastisitas

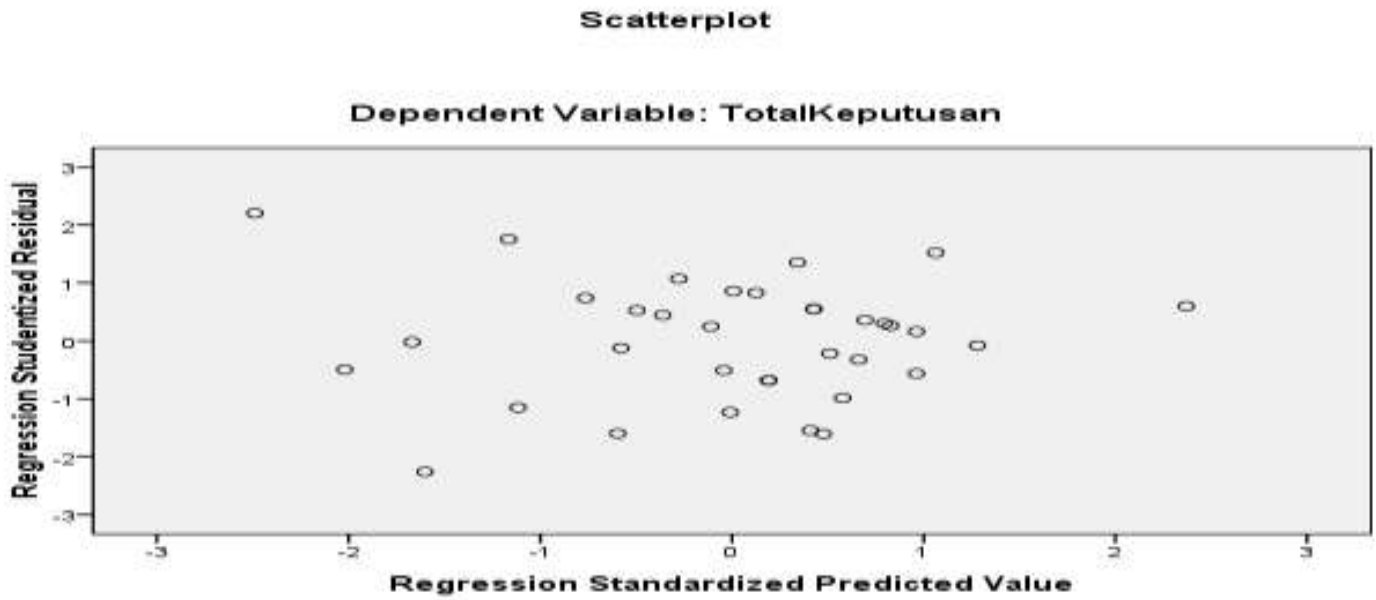

Gambar 4 - Hasil Pengujian Heteroskedastisitas Dengan Analisis Grafik Sumber: Hasil Pengolahan SPSS 16.0, $(n=35)$

\section{Analisis Regresi Linier Berganda}

Berdasarkan pengujian regresi linier berganda yang diolah dengan aplikasi SPSS 16.0 maka diperoleh hasil sebagai berikut:

Tabel 5 - Hasil Regresi Linier Berganda

\begin{tabular}{|l|c|}
\hline \multicolumn{1}{|c|}{ Model } & $\boldsymbol{t}$ \\
\hline Constant & 0.121 \\
\hline Total Pengakuan Mutu Jasa Program Studi & 0.3643 \\
\hline Total Pengakuan Mutu Institui & -0.287 \\
\hline
\end{tabular}

Sumber: Hasil Pengolahan SPSS 16.0, $(\mathrm{n}=35)$

Dalam hasil ini juga membentuk persamaan regresi sebagai berikut: $\mathrm{Y}=\mathbf{0 , 1 2 1}+\mathbf{0 , 3 6 4 3}$ $\mathrm{X}_{1}-\mathbf{0 , 2 8 7} \mathrm{X}_{2}+\mathrm{e}$.
Berdasarkan aplikasi SPSS 16.0 maka diperoleh hasil untuk koefisien determinasi sebagai berikut:

\section{Koefisien Determinasi}

Tabel 6 - Model Summary

\begin{tabular}{|c|c|c|c|}
\hline $\boldsymbol{R}$ & $\begin{array}{c}\boldsymbol{R} \\
\text { Square }\end{array}$ & Adjusted R Square & Std.Error of the estimate \\
\hline 0.597 & 0.356 & 0.316 & 1.44740 \\
\hline
\end{tabular}

Sumber: Hasil Pengolahan SPSS 16.0, $(\mathrm{n}=35)$

Korelasi berganda antara pengakuan mutu jasa program studi dan mutu institusi terhadap keputusan mahasiswa dalam memilih jasa pendidikan adalah sebesar 0.597. Sementara koefisien determinasi sebesar 0.356 yang berarti bahwa variasi keputusan mahasiswa dalam memilih jasa pendidikan dapat dijelaskan oleh variasi pengakuan mutu jasa program studi dan mutu institusi sebesar 35,6 persen. Bila melihat 
koefisien yang telah dikoreksi dengan jumlah varian dan ukuran sampel (dapat mengurangi unsur bias bila ukuran sampel ditambah) yakni sebesar 31.6 persen.

Tabel 7 - ANNOVA

\begin{tabular}{|c|c|}
\hline $\boldsymbol{F}$ & Sig \\
\hline 8.862 & 0.001 \\
\hline
\end{tabular}

Sumber: Hasil Pengolahan SPSS 16.0, $(n=35)$

Berdasarkan tabel 7 di atas, dapat dijelaskan bahwa titik kesalahan yang terjadi jika nilai $F$ hitung sebesar 8.862 sebesar 0.001 di mana nilai ini lebih kecil dari 0.05.
Hal ini dapat diartikan bahwa peubah bebas secara bersama mampu menjelaskan perubahan pada peubah gayut atau dengan kata lain model dinyatakan fit.

Tabel 8 - Coefficient

\begin{tabular}{|c|c|c|}
\hline Model & $\boldsymbol{t}$ & Sig \\
\hline Constant & 0.121 & 0.904 \\
\hline Total Pengakuan Mutu Jasa Program Studi & 0.3643 & 0.001 \\
\hline Total Pengakuan Mutu Institui & -0.287 & 0.776 \\
\hline
\end{tabular}

Sumber: Hasil Pengolahan SPSS 16.0, $(\mathrm{n}=35)$

Berdasarkan tabel 8 di atas, dapat dijelaskan bahwa besarnya tingkat kesalahan pada nilai t-akreditasi yang diperoleh yakni sebesar 0.3643, dan karena nilai sig akreditasi (0.001) lebih kecil dari 0.05 dan arah koefisien positif maka pengakuan mutu program Magister Manajemen (X1) memiliki pengaruh terhadap keputusan mahasiswa dalam memilih jasa pendidikan.

Besarnya tingkat kesalahan pada nilai tTotal Pengakuan Mutu Institusi yang diperoleh yakni sebesar -0.287 , dan karena nilai sig akreditasi (0.776) lebih besar dari 0.05 dan arah koefisien negatif maka pengakuan mutu institusi (X2) tidak memiliki pengaruh terhadap keputusan mahasiswa dalam memilih jasa pendidikan (Y).

Dengan demikian, berdasarkan hipotesis yang telah dikemukakan sebelumnya dapat disimpulkan bahwa penelitian ini menjawab pernyataan hipotesis yang ada, yaitu:

a. Keputusan mahasiswa memilih jasa pendidikan dipengaruhi oleh pengakuan mutu jasa program studi (Hipotesis 1).

b. Keputusan mahasiswa memilih jasa pendidikan tidak dipengaruhi oleh pengakuan mutu institusi (Hipotesis 2).

c. Secara bersama, keputusan mahasiswa memilih jasa pendidikan dipengaruhi oleh pengakuan mutu jasa program studi dan pengakuan mutu institusi dengan (Hipotesis $3)$. 
Perbandingan Penelitian Terdahulu

Tabel 9 Penelitian Terdahulu

\begin{tabular}{|c|c|c|c|}
\hline Peneliti & Tahun & Hasil & Keterangan \\
\hline Moturi \& Mbithi & 2015 & $\begin{array}{l}\text { ISO 9001:2008 memiliki pengaruh pada } \\
\text { kualitas institusi pendidikan di Nairobi } \\
\text { termasuk kepuasan pelanggan dan } \\
\text { proses pengajaran di institusi pendidikan }\end{array}$ & $\begin{array}{lr}\text { Secara } & \text { parsial } \\
\text { mendukung } & \text { ISO } \\
9001: 2008 \text { yang } & \text { memiliki } \\
\text { pengaruh } & \text { kepada } \\
\text { mahasiswa } & \end{array}$ \\
\hline Christian, Michael & 2012 & $\begin{array}{l}\text { Pengakuan Pengakuan mutu jasa } \\
\text { pendidikan tinggi dan ISO } 9001 \text { baik } \\
\text { secara parsial maupun simultan } \\
\text { mempengaruh kilas balik keputusan } \\
\text { mahasiswa dalam memilih program } \\
\text { studi }\end{array}$ & $\begin{array}{l}\text { Secara parsial, hanya } \\
\text { Pengakuan Pengakuan } \\
\text { mutu jasa pendidikan } \\
\text { tinggi yang didukung dan } \\
\text { mendukung secara } \\
\text { simultan }\end{array}$ \\
\hline $\begin{array}{l}\text { Gamboa, Antonio } \\
\text { Jorge \& Melao, Nuno } \\
\text { Felipe }\end{array}$ & 2012 & $\begin{array}{l}\text { Faktor-faktor dalam ISO } 9001 \text { memiliki } \\
\text { pengaruh pada institusi pendidikan } \\
\text { secara keseluruhan }\end{array}$ & $\begin{array}{lr}\text { Secara } & \text { parsial } \\
\text { mendukung } & \text { ISO } \\
9001: 2008 \text { yang } & \text { memiliki } \\
\text { pengaruh } & \text { kepada } \\
\text { mahasiswa } & \\
\end{array}$ \\
\hline $\begin{array}{l}\text { Sumaedi \& Bakti, I } \\
\text { Gede Mahatma Yuda }\end{array}$ & 2011 & $\begin{array}{l}\text { Terdapat pengaruh yang signifikan } \\
\text { antara kepuasan yang diterima dari sisi } \\
\text { kualitas layanan pada sekolah yang telah } \\
\text { menerapkan ISO } 9001 \text { dengan sekolah } \\
\text { yang belum menerapkan }\end{array}$ & $\begin{array}{lr}\text { Secara } & \text { parsial } \\
\text { mendukung } & \text { ISO } \\
9001: 2008 \text { yang } & \text { memiliki } \\
\text { pengaruh } & \text { kepada } \\
\text { mahasiswa } & \\
\end{array}$ \\
\hline Lutfhi, Teuku Haekal & 2011 & $\begin{array}{l}\text { Klausul ISO 9001:2008, standar BAN } \\
\text { PT, dan kriteria AUN QA memiliki } \\
\text { keterikatan satu sama laian dan } \\
\text { mendukung dalam pengintegrasian } \\
\text { Sistem Manajemen Mutu }\end{array}$ & $\begin{array}{lr}\text { Secara } & \text { parsial } \\
\text { mendukung } & \text { ISO } \\
9001: 2008 \text { dan BAN PT }\end{array}$ \\
\hline
\end{tabular}

Sumber: peneliti

Hasil penelitian ini sejalan dengan hasil penelitian yang dilakukan oleh Moturi \& Mbithi (2015) yang menjelaskan bahwa mutu pendidikan tinggi (raihan sertifikasi ISO 9001:2008) memberikan dampak yang signifikan salah satunya pada kepuasan pelanggan. Secara simultan, hasil penelitian ini sama dengan penelitian yang dilakukan leh Christian, Michael (2012) dimana keputusan mahasiswa memilih program magister secara bersama dipengaruhi oleh mutu jasa program studi dan mutu institusi, namun secara parsial keputusan mahasiswa memilih program magister yang dipengaruhi oleh mutu institusi memiliki hasil yang berbeda. Gamboa, Antonio Jorge \& Melao, Nuno Felipe (2012) menyimpulkan bahwa mutu institusi memberikan manfaat baik secara internal maupun internal. Aspek internal seperti kepuasan mahasiswa sangat dipengaruhi oleh kualitas yang diberikan institusi yang dapat diimplementasikan dengan sistem manajemen bebasis ISO 9001 (Sumaedi \& Bakti, I Gede Mahatma Yuda, 2011). Secara keseluruhan penerapan mutu jasa program studi dan mutu institusi seperti raihan akreditasi program studi dan ISO 9001:2008 bila dilakukan secara terintegrasi akan memberikan banyak keuntungan pada institusi (Lutfhi, Teuku Haekal, 2011). 


\section{Kesimpulan dan Saran \\ Kesimpulan}

Berdasarkan pembahasan sebelumnya, maka hasil penelitian ini dapat disimpulkan sebagai berikut:

1. Keputusan mahasiswa dalam memilih jasa pendidikan di Universitas Swasta X di Jakarta dipengaruhi oleh pengakuan mutu jasa program studi.

2. Keputusan mahasiswa dalam memilih jasa pendidikan di Universitas Swasta X di Jakarta tidak dipengaruhi oleh pengakuan mutu institusi.

3. Keputusan mahasiswa dalam memilih jasa pendidikan di Universitas Swasta X di Jakarta secara bersama tidak dipengaruhi oleh pengakuan mutu jasa program studi dan pengakuan mutu institusi.

\section{Saran}

Dari simpulan di atas, dapat dipaparkan beberapa saran sebagai berikut:

1. Pada faktor pengakuan mutu jasa program studi dalam penelitian ini, penyampaian informasi pentingnya keterkaitan mata kuliah yang didesain terhadap kepentingan industri pekerjaan mahasiswa perlu ditingkatkan lagi, misalnya dengan memberikan studi kasus yang lebih varian yang menggunakan industri dimana mahasiswa bekerja.

2. Untuk keperluan penelitian selanjutnya, peubah gayut dapat ditambahkan dengan peubah lain, misalnya raihan IWA 2, reputasi badan akreditasi, dan sebagainya.

\section{Daftar Pustaka}

Christian, Michael. 2012. Pengaruh Pengakuan Pengakuan Mutu Jasa Pendidikan Tinggi dan ISO Terhadap Kilas Balik Keputusan Mahasiswa Memilih Program Studi. Tesis. Universitas Bunda Mulia

Gamboa, Antonio Jorge \& Melao, Nuno Felipe. 2012. The Impact of Success Factors of ISO 9001 in Education: Experience From Portuguese Vocational School". Emerald International Journal of Quality \& Reliability Management Vol. 29 No. 4
Gasperz, Vincent. 2006. ISO 9001:2008\&

Continual Improvement. Gramedia Pustaka.

Hurriyati, Ratih. 2008. Bauran Pemasaran dan Loyalitas Konsumen. Alfabeta, Bandung.

Junior, et al,. 2003, AACSB Accreditation From The Faculty Perspective, h.11.

Khan, Matin. 2006, "Consumer Behaviour and Advertising Management". New Age International Publisher. New Delhi.

Lutfhi, Teuku Haekal. 2011. Perancangan Sistem Manajemen Mutu Terintegrasi Dengan Metode Pendekatan Proses Dan Pedoman Dokumentasi: Untuk Program Studi di Perguruan Tinggi Indonesia. Tesis. Universitas Indonesia.

McCauley, Mary Ann. 2003. The Value of Accreditation: Communication, World 24. A5", h.11

Melyana. 2010. Pengaruh ISO 9001:2000, Kualitas Produk dan Layanan Terhadap Keputusan Pembelian Produk Genteng pada PT Prima Manunggal Inti Internusa, h;4950.

Menon, et al. 2007. Quality Indicators for Teacher Education : National Assesment and Accreditation Council", Banglore, India dan Commonwealth of Learning, h. 1-26. Vancouver, Canada.

Moturi \& Mbithi. 2015 : “ISO 9001: 2008 Implementation and Impact on The University of Nairobi: A Case Study", The TQM Vol. 27 No. 6, pp. 752-760

Supranto, J. 2000. Metode Ramalan Kuantitatif Untuk Perencenaan Ekonomi dan Bisnis. Rineka Cipta. Jakarta.

Sekaran, Uma. 2006. Research Methods for Business, 4th Edition., John Wiley \& Sons. Inc, New York. 
Suliyanto. 2011. Ekonometrika Terapan. Andi. Yogyakarta

Sumaedi \& Bakti. 2011. The Students' Perceived Quality Comparison of ISO 9001 and Non-ISO 9001 Certified School: an
Empirical Evaluation. International Journal of Engineering \& Technology IJET-IJENS Vol: 11 No: 01.

http://ban-pt.kemdiknas.go.id, diakases pada 10 Januari 2016 